\title{
Birinci basamak alektinib tedavisi alan ALK mutasyonu pozitif akciğer kanseri hastalarının klinik özelliklerinin değerlendirilmesi
}

\author{
Mutlu $\operatorname{HIZAL}^{1}(I D)$ \\ Burak BíLGiN² ${ }^{2}$ (ID) \\ Mehmet Ali \\ SENDUR $^{3}$ (ID) \\ Şebnem YÜCEL ${ }^{2}(I D)$ \\ Seda KAHRAMAN ${ }^{3}$ (ID) \\ Cihan $\operatorname{EROL}^{3}($ ID) \\ Bülent $\mathrm{AKINCI}^{3}$ (ID) \\ Didem ŞENER DEDE ${ }^{3}$ (ID) \\ Efnan ALGIN ${ }^{1}$ (ID) \\ Bülent YALÇIN ${ }^{3}$ (ID)
}

\author{
${ }^{1}$ Ankara Şehir Hastanesi, Tıbbi Onkoloji Kliniği, Ankara, Türkiye \\ ${ }^{1}$ Clinic of Medical Oncology, Ankara City Hospital, Ankara, Turkey \\ ${ }^{2}$ Atatürk Göğüs Hastalıkları ve Göğüs Cerrahisi Eğitim ve Araştırma \\ Hastanesi, Tıbbi Onkoloji Kliniği, Ankara, Türkiye \\ ${ }^{2}$ Clinic of Medical Oncology, Atatürk Chest Diseases and Chest Surgery \\ Training and Research Hospital, Ankara, Turkey \\ ${ }^{3}$ Yıldırım Beyazıt Üniversitesi Tıp Fakültesi, Tıbbi Onkoloji Bilim Dalı, \\ Ankara, Türkiye \\ ${ }^{3}$ Division of Medical Oncology, Yıldırım Beyazıt University Faculty of Medicine, \\ Ankara, Turkey
}

Makale atıfı: Hızal $M$, Bilgin B, Sendur MA, Yücel S, Kahraman S, Erol C ve ark. Birinci basamak alektinib tedavisi alan ALK mutasyonu pozitif akciğer kanseri hastalarının klinik özelliklerinin değerlendirilmesi. Tuberk Toraks 2021;69(3):321-327.

Yazışma Adresi (Address for Correspondence)

Dr. Mutlu HIZAL

Ankara Şehir Hastanesi,

Tıbbi Onkoloji Kliniği,

ANKARA - TÜRKIYE

e-mail: drmutluhizal@hotmail.com

CTelif Hakkı 2021 Tüberküloz ve Toraks. Makale metnine www.tuberktoraks.org web adresinden ulașılabilir.
ÖZ

Birinci basamak alektinib tedavisi alan ALK mutasyonu pozitif akciğer kanseri hastalarının klinik özelliklerinin değerlendirilmesi

Giriş: Akciğer kanseri tüm dünyada cinsiyet ayırt etmeksizin en sık görülen ve en sık mortaliteye neden olan kanser tipidir. Tüm küçük hücre dışı akciğer kanseri (KHDAK) hastalarının \%3-7'sinde anaplastik lenfoma kinaz (ALK) mutasyonu pozitif olarak saptanır. Bu iki merkezli çalışma ile ALK mutasyonu olan ve birinci basamak alektinib tedavisi alan KHDAK hastaların patolojik, klinik, demografik özelliklerinin araştırılması amaçlanmıştır.

Materyal ve Metod: Ankara Şehir Hastanesi Tıbbi Onkoloji ve Atatürk Göğüs Hastalıkları ve Göğüs Cerrahisi Eğitim ve Araştırma Hastanesi Tıbbi Onkoloji bölümlerinde takipli olan, KHDAK tanısı almış ve ALK mutasyonu pozitif gelen, tirozin kinaz inhibitörü olarak birinci basamakta Alektinib tedavisi alan hastalar retrospektif olarak incelendi.

Bulgular: Çalışmaya toplam 38 hasta (15 erkek, 23 kadın) dahil edildi. Ortanca yaş 56,5 olarak bulundu. Hastaların \%55,3'ünün hiç sigara içmediği, tümünün adenokanser alt tipinde olduğu saptandı. Otuz dört hasta $(\% 89,5)$ metastatikti. Beyin metastazı \%44,7 oranında saptandı. Otuz üç hastanın $(\% 86,8)$ birinci basamakta alektinib kullandığı görüldü. Geri kalan beş hastanın daha önce en az bir kür kemoterapi tedavisi aldığı görüldü. Alektinib tedavisiyle objektif yanıt oranı \%78,9 gözlendi. En az bir tane yan etki bildirilen hasta oranının \%34,2; ciddi yan etki görülen hasta oranının \% 7,9 olduğu 
saptandı. Ortanca 9,5 ay takipten sonra, ortanca progresyonsuz sağkalıma (PS) ulaşılamadı. 24-aylık PS \% 67, 24 aylık genel sağkalım $\% 84$ olarak bulundu.

Sonuç: Çalışmamıza alınan hasaların sonuçları incelendiğinde klinik, patolojik ve demografik verilerinin geçmiş çalışmalarla uyumlu olduğu görülebilir. Sigara içmeyen, göreceli olarak genç, kadın hastaların çoğunlukta olduğu görülmüştür. Alektinib tedavisiyle literatürle benzer yanıt oranı ve sağkalım sonuçları alınabileceği görülmüştür.

Anahtar kelimeler: ALK mutasyonu; akciğer kanseri; alektinib; klinik özellikler

\begin{abstract}
Clinical features of the ALK-mutant non-small cell lung cancer patients who received first-line alectinib treatment

Introduction: Lung cancer is the most common cancer type and the leading cause of cancer-related mortality worldwide. The positivity rate of the anaplastic lymphoma kinase (ALK) mutation in non-small cell lung cancer (NSCLC) patients has been reported as 3-7\%. This study aimed to investigate the pathological, clinical and demographic characteristics of ALK-mutant NSCLC patients who received first-line alectinib as a tyrosine kinase inhibitor in two different centers.
\end{abstract}

Materials and Methods: The study was performed at the Medical Oncology Departments of Ankara City Hospital and Atatürk Chest Diseases and Thoracic Surgery Training and Research Hospital. Patients diagnosed with ALK-mutant NSCLC and received alectinib treatment as a first-line tyrosine kinase inhibitor were enrolled to study and retrospectively analyzed.

Results: A total of 38 patients (15 males, 23 females) were included in the study. Median age was 56.5. 55.3\% of the patients were non-smokers. All of the patients had adenocarcinoma histology. Thirty-four patients (89.5\%) were metastatic. Brain metastasis was detected in $44.7 \%$ of the patients. Thirty-three patients (86.8\%) were using alectinib in first-line treatment. The remaining five patients were seen to have received at least one course of chemotherapy before. The objective response rate was $78.9 \%$ with alectinib treatment. The percentage of the patients who experienced at least one side effect was $34.2 \%$ and serious side effects were $7.9 \%$. After median 9.5 months follow-up, median progression-free survival (PFS) was not achieved. 24-month PFS was 67\% and 24-month overall survival was $84 \%$.

Conclusion: Our results were compatible with previous studies in terms of the clinical, pathological and demographic features of the patients with ALK mutation. We observed that the majority of patients were non-smokers, relatively young, and female patients. The objective response rate and survival results were similar with phase 3 studies.

Key words: ALK mutation; lung cancer; alectinib; clinical features

\section{Giriş}

Akciğer kanseri, tüm dünyada cinsiyet ayırt etmeksizin en sık görülen ve en sık mortaliteye neden olan kanser tipidir. Tüm dünyada kanser vakalarının $\% 11,6$ 'sını oluşturur ve kanser ilişkili ölümlerin $\% 18,4$ 'ünden sorumludur (1). Akciğer kanserlerinin çoğunluğunu oluşturan küçük hücre dışı akciğer kanserleri (KHDAK) ise temel olarak adenokanser ve skuamöz hücreli kanser olarak iki alt tipe ayrılır. 2009-2015 arası dönemi kapsayan bir çalışmada, Amerika Birleşik Devletleri (ABD) verilerine göre KHDAK hastalarının beş yıllık genel sağkalım (GS) oranı $\% 25$ olarak bildirilmiştir ve özellikle metastatik hastalıkta beş yıllık GS \%10'un altına inmektedir (2).

Oldukça heterojen bir başlık olan KHDAK'deki bu olumsuz tablo, özellikle son iki dekatta sürücü -driver- mutasyonların keşfi, tümör ve mikroçevresinin moleküler ve immünolojik olarak daha iyi aydınlatılması, hedeflenmiş tedavilerin ve immünoterapilerin geliştirilmesiyle seçili hasta grupları için anlamlı şekilde değişikliğe uğramıştır $(3,4)$. Bu sürücü mutasyonlar arasında sıklık ve/veya tedavi hedefi olması anlamında en önemlileri KRAS, EGFR, ALK, ROS, BRAF, Ret, Met, Her-2 olarak sıralanabilir.

Anaplastik lenfoma kinaz (ALK) mutasyonu görülme sıklığı farklı çalışmalarda tüm KHDAK hastalarının \%3-7'sinde pozitif olarak bildirilmiştir (5). Bu vakaların neredeyse tamamı adenokanserlerden oluşmaktadır. Farklı varyantları olmasına rağmen özellikle 2. Kromozomun kısa kolunun inversiyonuna bağlı olarak oluşan EML4 (echinoderm microtubule-associated protein-like 4) ve ALK füzyonu, hücre içi bölgedeki tirozin kinaz bölgesini sürekli aktif halde tutar. Normal şartlarda embriyo aşamasından başlayan ve özellikle hücresel iletişim, nöronal gelişim ve diferansiyasyonda öncü rol oynayan ALK reseptörü EML4ALK füzyon mutasyonu sonrası potent onkojenik etkiye sahip olur (6). ALK-mutant hastalık, KHDAK ortalamasını yansıtan parametrelerden klinik, histomorfolojik, prognostik olarak ayrışır ve farklı bir klinik antite ortaya koyar. Özellikle santral sinir sistemi tutulumunun sık görülebildiği, genel olarak hastaların yaş ortalamasının daha genç ve \%70-80 sigara maruziyeti olmadığı bildirilmiştir (7). 
ALK-mutant KHDAK tedavisinde ise farklı jenerasyonlarda etkinliği artan birçok tirozin kinaz inhibitörü kullanılmaktadır. Hastalığın tedavisinde etkinliğini ilk gösteren ve kullanılmaya başlayan Crizotinib olmuş ancak sonrasında brigatinib, alektinib, lorlatinib gibi yeni jenerasyon farklı ajanlar kullanıma girmiştir. Alektinib, santral sinir sistemine geçişi olan, birçok farklı ilaç direnç mutasyonu varlığında etki edebilen potent bir ALK tirozin kinaz inhibitörüdür. ileri evre ALK-mutant hastaların birinci basamak tedavisinde etkinliğini faz 3 çalışmalarla kanıtlamıştır (8-10). Söz konusu bu üç tane faz 3 çalışma birinci basamakta crizotinib tedavisine karşı ve farklı etnik/ coğrafi kökene (Batı, Doğu Asya, Japonya) sahip katılımcılar üzerinde yapılmıştır. Ülkemizde de alectinib tedavisi 2018 yılından bu yana ileri evre ALK-mutant KHDAK birinci basamak tedavisinde kullanılmaktadır.

Bu iki merkezli çalışmayla ALK mutasyonu olan ve birinci basamak Alektinib tedavisi alan KHDAK hastaların patolojik, klinik, demografik özelliklerinin araştırılması ve sağkalım sonuçlarının değerlendirilmesi amaçlanmıştır. Böylece çok sık rastlanmayan bu mutasyon varlığında diğer KHDAK türlerinden farklı özellikler gösterebilen hastalığın bu alt grubuyla ilgili literatüre katkı sunmak amaçlanmıştır.

\section{MATERYAL ve METOD}

Ankara Şehir Hastanesi Tıbbi Onkoloji ve Atatürk Göğüs Hastalıkları ve Göğüs Cerrahisi Eğitim ve Araştırma Hastanesi Tıbbi Onkoloji bölümlerinde takipli olan, KHDAK tanısı almış ve ALK mutasyonu pozitif gelen, tirozin kinaz inhibitörü olarak birinci basamakta en az bir doz alektinib tedavisi almış olan 18 yaş üzeri hastalar çalışmaya dahil edilmiştir. Hastalar ilgili kliniklerde ülkemizde alektinib birinci basamak tedavi onayı aldıktan sonra yani 03/201801/2021 yıllarında takip edilmiş hastalardır. Birinci basamakta tirozin kinaz inhibitörü tedavisi olarak alektinib tedavisi alan hastalar dahil edildi. Yani durumu aciliyet arz eden vakalarda veya ülkemiz koşulları gereği patoloji sonucu gecikebilen veya sonrasında konfirme edilen vakalarda olduğu gibi, bazı hastaların ALK mutasyon sonucu gelene dek kemoterapi tedavisi alabildiği göz önünde bulundurularak bu hastalar da çalışmaya dahil edildi. En az bir kür kemoterapi almış hastalar bir basamak tedavi almış kabul edildi. Alektinib öncesi kemoterapi dışı herhangi bir hedeflenmiş tedavi veya immünoterapi almış hastalar çalışmadan dışlandılar.
Hastalara ait klinik, patolojik, demografik özellikler hasta dosyalarından ve elektronik kayıt sistemleri incelenerek retrospektif olarak değerlendirilmiştir. Hastaların klinik ve demografik özellikleri olarak cinsiyet, yaş, tanı tarihi, sigara içme durumu ve içtiyse ne kadar süre kullandığı, hastalık evresi, metastaz olan hastalarda metastaz yerleri, tedaviye başlama tarihleri, görülen yan etkiler ve derecesi, hastalığın progresyon gösterdiği veya eksitus tarihleri incelendi.

Alektinib tedavisi başlandıktan sonra yanıt değerlendirmesi RECIST (Response Evaluation Criteria in Solid Tumors) kriterlerine ve yan etkiler National Cancer Institute Common Terminology Criteria for Adverse Events (AEs) 4.0 versiyonuna göre yapıldı $(11,12)$. Progresyonsuz sağkalım süresi (PS), tedavinin başlangıcından hastalığın ilerlemesi veya ölüme kadar geçen süre (ay) olarak hesaplanarak bulundu. Genel sağkalım (GS), tanıdan hastanın ölümüne veya hastanın klinikte son değerlendirme gününe kadar geçen süre (ay) olarak hesaplanarak bulundu.

Veriler, SPSS 22.0 yazılım programı kullanılarak analiz edildi. Sürekli değişkenler ortanca veya ortalama, minimum, maksimum değerleri ile birlikte kategorik değişkenler; frekans tabloları ve yüzdeleri ile verildi. Sağkalım analizleri Kaplan-Meier metoduyla değerlendirildi. Ortanca değere ulaşmayan sağkalım parametrelerinin değerlendirilmesinde yaşam tablosu yöntemi kullanıldı. İstatistiksel anlamlılık için $\mathrm{p}<$ 0,05 değeri kriter olarak kabul edildi. Ankara Şehir Hastanesi Klinik Araştırmalar Etik Kurulundan onay alındı.

\section{BULGULAR}

Çalışmaya Ankara'daki iki farklı merkezden toplam 38 hasta dahil edildi. Hastaların ortanca yaşı 56,5 (min-maks.: 26-79) olarak bulundu. Hastaların 15 tanesi $(\% 39,5)$ erkek ve 23 tanesi $(\% 60,5)$ kadındı.

Sigara açısından değerlendirilen hastaların \%55,3 ( $n=21$, erkek/kadın: 3/18)'ünün hiç sigara içmediği, 13 tanesinin $(\% 34,2)$ bırakmış olduğu ve dört kişinin ise $(\% 10,5)$ aktif olarak sigara içicisi olduğu gösterildi. Sigara maruziyeti olan 17 kişinin paket-yıl üzerinden yapılan sigara içme süresi ortanca 20 paket-yıl (min-maks.: 5-60) olarak hesaplandı.

Tüm hastaların histolojik alt tipi adenokanser olarak saptandı. Lokal ileri ancak lokal tedavilere uygun olmayan dört hasta mevcuttu. Geri kalan 34 hasta $(\% 89,5)$ metastatikti. Sırasıyla akciğer \%50 ( $n=19)$, beyin $\% 44,7(n=17)$, kemik $\% 42,1(n=16)$, karaciğer 
Birinci basamak alektinib tedavisi alan ALK mutasyonu pozitif akciğer kanseri hastalarının klinik özelliklerinin değerlendirilmesi

Tablo 1. Hastaların klinik ve demografik özellikleri

\begin{tabular}{|llcc|}
\hline Özellik & $\mathbf{n ~ ( \% )}$ & Özellik & $\mathbf{n}(\%)$ \\
\hline Cinsiyet & \multicolumn{3}{c|}{ Evre } \\
$\quad$ Erkek & $15(\% 39,5)$ & Lokal ileri & $4(\% 10,5)$ \\
Kadın & $23(\% 60,5)$ & Metastatik & $34(\% 89,5)$ \\
Sigara & & Metastaz bölgesi & \\
İçmemiş & $21(\% 55,3)$ & Akciğer & $19(\% 50)$ \\
Bırakmış & Beyin & $17(\% 44,7)$ \\
Aktif içici & $13(\% 34,2)$ & Kemik & $16(\% 42,1)$ \\
& $4(\% 10,5)$ & Karaciğer & $10(\% 26,3)$ \\
& & Plevra & $10(\% 26,3)$ \\
Histoloji & Önceki kemoterapi & \\
Adenokanser & $38(\% 100)$ & Hiç & $33(\% 86,8)$ \\
Skuamöz hücreli & $0(\% 0)$ & Bir basamak & $4(\% 10,5)$ \\
Tiplendirilemeyen & $0(\% 0)$ & iki basamak & $1(\% 2,6)$ \\
\hline
\end{tabular}

ve plevra \%26,3 $(n=10)$ sıklıkta en sık metastaz saptanan bölgeler olarak tespit edildi. (Tablo 1)

Daha önce hedeflenmiş tedavi veya immünoterapi almayan hastalar alektinib aldıkları tedavi basamağına göre sınıflandırıldıklarında 33 hastanın $(\% 86,8)$ birinci basamakta alektinib kullandığı görüldü. Geriye kalan beş hastadan dört tanesi $(\% 10,5)$ daha önce bir basamak sitotoksik tedavi aldığı ve sadece bir hastanın alektinib öncesi iki basamak sitotoksik tedavi aldığı görüldü.

Alektinib tedavisi sonrası 36 hastanın yanıt değerlendirmesine ulaşıldı, iki hastanın yanıt değerlendirmesi yoktu. Toplam dört hastada tam yanıt $(\% 10,5)$ ve 26 hastada parsiyel yanıt $(\% 68,4)$ elde edildi. Böylece objektif yanıt oranı \%78,9 olarak hesaplandı. Kalan hastaların ikisinde stabil yanıt saptandı. Sadece dört hastada $(\% 10,5)$ alektinib tedavisi sonrası progresif hastalık olduğu görüldü. Progresyonu olan hastalar incelendiğinde üç hastanın alektinibi birinci basamak tedavi olarak aldığı, sadece bir hastanın daha önce bir basamak sitotoksik tedavi aldığı görüldü.

En az bir tane yan etki bildirilen hasta oranı \%34,2 olarak hesaplandı. Ilacın tolerabilitesinin ve yan etki profilinin kötü olmadığı, 3. veya 4. derece yan etki deneyimleyen üç hasta $(\% 7,9)$ olduğu saptandı. Yan etkiler sırasıyla karaciğer fonksiyon testlerinde yükselme $(\% 15,7)$, halsizlik veya miyalji $(\% 10,4)$, periferal ödem $(\% 7,9)$, anemi $(\% 5,2)$ olduğu görüldü. Yan etki nedeniyle doz redüksiyonu 10 hastada $(\% 26,3)$ görülürken, tedavi sonlandırma görülmedi.

Ortanca 9,5 ay (min-maks.: 1,8-24,9 ay) takipten sonra, ortanca PS'ye ulaşılamadı. Toplam 10 olay gözlenirken, 12-aylık PS \%74 ve 24-aylık PS \%67 olarak hesaplandı. Alektinibi birinci basamakta alan, daha önce herhangi bir sitotoksik tedavi almamış 33 hastada ise toplam olay sayısı yedi ve 24-aylık PS $\% 74$ olarak hesaplandı. Takip süresi sonunda toplam dört eksitus meydana geldi ve 12-aylık GS \%92 ve 24-aylık GS \%84 olarak hesaplandı.

\section{TARTIŞMA}

$\mathrm{Bu}$ çalışmada ALK mutasyonu pozitif hastaların 26-79 gibi yaş aralığının geniş bir aralığa dağılabileceği, hastaların çoğunluğunun sigara içmediği ve kadın cinsiyette olduğu saptanmıştır. Hastalar arasında skuamöz hücreli histolojiye rastlanmadığı ve hepsinin adenokanser alt tipinde olduğu, santral sinir sistemi metastazının neredeyse iki hastadan birinde bulunduğu gösterildi. Ayrıca birinci basamak tedavide alektinib tedavisinin klinik olarak anlamlı ve oldukça etkin bir yanıt oranına ulaştığı, ilacın tolerabilitesinin ve yan etki profilinin klinik olarak yönetilebilir olduğu saptandı.

ALK mutasyonu olan KHDAK hastalarının daha genç oldukları ve daha yüksek bir oranda sigara içmeyen hastalardan oluştukları yönünde çalışmalar mevcuttur. Journal of Clinical Oncology dergisinde 2009 yılında yayınlanan bir çalışmada ALK mutant hastaların klinik özellikleri incelenmiştir (13). Bu çalışma kadın cinsiyet, Asya etnisitesi, sigara içmemiş/hafif içici olmak ve adenokanser alt tipinde olmak şeklinde listelenen dört risk faktörü belirlemiş ve iki veya üstü risk faktörü olan 141 hastanın tümör örneğinde ALK ve EGFR mutasyonu varlığı araştırmıştır. Bu seçili populasyonda ALK mutasyon varlığı \%13 olarak 
saptanmıştır (13). Bu 19 ALK-mutant hastanın ortanca yaş değeri 52 olarak bildirilmiştir ve bizim çalışmamızın 56,5 ortanca değerine (min-maks.: 26-79) oldukça yakındır. Ayrıca yaş aralığı bahsedilen çalışmada 29-76 aralığındadır ve bu değer aralığı da çalışmamızla neredeyse birebir uyum içerisindedir. ALK-mutant hastaların EGFR-mutant veya her iki mutasyonu taşımayan diğer hasta gruplarıyla karşılaştırıldığında istatistiksel olarak anlamlı şekilde daha genç oldukları yine aynı çalışmada bildirilmiştir (13). Uzak Doğu kökenli başka bir araştırmada ALKmutant hastaların klinik özellikleri mutasyonu olmayan olgularla karşılaştırılmıştır (7). Bu çalışmada ALK-mutant hastalarda $(n=45)$ ortanca yaş 49 olarak bildirilmiştir. Daha önemlisi dekatlar halinde hastaların yüzdeleri verilmiştir ve hastaların yarısından fazlasının 40-60 yaş arasında kümelendiği görülmüştür. Hastalık sürücü mutasyonu olmayan hastalara göre daha genç bir yaş aralığında prezente olmakla birlikte, klinik pratikte yaşlı hastalarda da mutasyonun saptanabileceği unutulmamalıdır. Bizim çalışmamızın üst yaş sınırı 79 yaştır ve az önce bahsedilen Uzak Doğu kökenli çalışmada da 70-79 yaş arası görülme sıklığı \%6,7 olarak bildirilmiştir (7).

Cinsiyet açısından farklı çalışmalarda ALK-mutant kohortlar arasında kadın cinsiyet oranı yaklaşık \%42$\% 48$ olarak bildirilmiştir $(7,13,14)$. Bizim çalışmamızda kadın cinsiyet sıklığı \%60,5 olarak saptandı. Klinik özelliklerin araştırıldığı mevcut çalışmalardan biraz daha yüksek izlenimi veren bu oran ülkemizde kadın cinsiyette sigara içme sıklığının daha az olmasına bağlanabilir. Diğer taraftan faz 3 çalışmalardan en önemlisi olan ve Asya kökenli olan ve olmayan hastaların eşit şekilde temsil edildiği ALEX çalışmasına randomize edilen hastalardaki kadın cinsiyet oranı yine \%55-58 olarak bildirilmiştir (8).

Tüm hastaların adenokanser alt tipinde olması bir diğer önemli bulgudur. Bu durum iki temel nedenle açıklanabilir: Birincisi, ALK mutasyonu adenokanserlere göre skuamöz hücreli alt tipte daha az sıklıkta görülür. Skuamöz hücreli alt tipine sahip 221 hastanın analiz edildiği bir çalışmada sadece üç hastada $(\% 1,3)$ ALK mutasyonu saptanmıştır (15). Çalışmamızda hasta sayısının azlığı nedeniyle adenokanser dışı alt tiplere rastlanmamış olabilir. İkinci nedeniyse ALK mutasyonunun adenokanser alt tipinde mutlaka bakılması önerilirken, skuamöz hücreli kanserlerde klinik pratikte hasta özelliklerine bağlı olarak daha az test edilebilmesidir (16).
Çalışmamızda hastaların \%55,3'ünün hiç sigara içmediği gösterilmiştir. Aktif sigara içen dört hasta $(\% 10,5)$ mevcuttu. Yine literatürdeki farklı çalışmalarda ALK-mutant hasta gruplarında hiç sigara içmemiş hasta oranlarının yaklaşık \%42-59 arasında bildirildiğini görüyoruz $(7,13,14)$. Literatürdeki çalışmaların bazılarında "hafif içici" olarak tanımlanan ve genelde $\leq 10$ paket-yıl sigara içen hastalar, hiç sigara içmeyen hastalarla beraber sınıflandırılabilmektedir. Bununla beraber sonuçların çalışmamızla uyumlu olduğu söylenebilir. Ayrıca sigara içmeyen hastaların sadece üç tanesinin erkek olup, 18 tanesinin kadın olması çalışmadaki \%60'ıı kadın cinsiyet temsilini ve ülkemizde sigara içiminin kadınlar arasında daha az sıklıkta olduğunun bir yansıması olarak değerlendirilebilir.

KHDAK hastalarında santral sinir sisteminin sık görülen bir metastaz bölgesi olduğu bilinmektedir. Bununla beraber ALK mutasyonu taşıyan alt grubun diğer hastalara kıyasla beyin metastazı gelişimi açısından daha yüksek riskli olduğu bildirilmiştir (17). $A B D$ verilerine dayanan ve bir milyonun üstünde hastanın analiz edildiği çalışmada ALK-mutant 947 hastanın bulunduğu alt grupta tanı anını takip eden ilk üç ay içerisinde beyin metastazı saptanma oranı \%28 olarak bulunmuştur (18). Yine ALK mutasyonu olan ve tümü beyin metastazı olan 90 hasta içeren başka bir retrospektif çalışmada tanı anında beyin metastazı oranı \%30'dur ve kalan \%70 hastanın beyin metastazı geliştirme süresi ortanca 27 ay (2-174 ay) olarak hesaplanmıştır (19). Bizim çalışmamızda beyin metastazı görülme sıklığı \%44,7 olarak bulunmuştur. Bu oran eski çalışmalara göre yaklaşık \%15 daha yüksektir. Çalışmamızda daha önce sitotoksik tedavi alan beş hastanın üç tanesinde beyin metastazı vardır. Çalışmaya katılan hasta ve merkez sayısının kısıtlı olması bir diğer neden olabilir. Ayrıca çalışmaya katılan hastalar 2018 yılından sonrasını temsil etmektedir. Haliyle, ALK-mutasyonu olan hastalarla ve SSS tutulumuyla ilgili klinik bilgi ve deneyimin artması, bu hastaların diğer KHDAK hastalarının aksine daha sık ve düzenli aralıklarla kranial görüntülemeyle takip edilmesine neden olmuş olabilir. Faz 3 ALEX çalışmasında ise randomize edilen hastalardan alektinib kolunda beyin metastazı görülme oranı \%42 ile yine çalışmamıza yakın bir değerdedir (8).

Alektinib, ALK mutasyonu olan ileri evre KHDAK hastalarının birinci basamak tedavisinde crizotinib 
tedavisine karşı etkinliğini farklı populasyonlarda gerçekleştirilen üç farklı faz 3 çalışmayla kanıtlamıştır (8-10). Uzak Doğu ülkeleri olan Çin, Güney Kore ve Tayland'ta gerçekleştirilen ve 125 hastanın alektinib koluna randomize edildiği çalışmada alektinib tedavisiyle PS'de \%78 risk azalması saptanmıştır (10). Japonya'da çok merkezli gerçekleştirilen J-ALEX çalışmasında ise alektinib koluna 103 hasta randomize edilmiş ve yarı dozda tedaviyle bu populasyonda alektinib, birinci basamakta crizotinibe karşı PS'de $\% 66$ risk azalma göstererek primer sonlanım noktasını karşılamıştır (9).

Elbette sadece Uzak Doğu değil genel dünya populasyonunu temsil etme gücüyle ve katılımcı sayısının üstünlüğüyle ALEX çalışması üç farklı faz 3 çalışması içerisinde en önemli yere sahiptir (8). Bu randomize faz 3 çalışma ALK-mutant ileri evre KHDAK hastalarının birinci basamak tedavisinde crizotinib tedavisine karşı Alektinib tedavisini değerlendirmeyi amaçlamıştır. Toplam 303 hasta 1:1 oranında iki tedavi koluna randomize edilmiştir. Toplam 98 farklı merkezde gerçekleştirilen çalışmada alektinib kolundaki hasta $(\mathrm{n}=$ 152) özelliklerine bakıldığında ortanca yaşın 58, kadın cinsiyet oranının \%55, Asyalı olmayan etnisite oranının \%55, sigara içmeyenlerin \%61, hastaların neredeyse tamamının evre IV (\%97) ve adenokarsinoma (\%90) histolojisinde olduğu, beyin metastazı olan hasta oranının ise \%42 olduğu görülebilir. Çalışma ortanca 18,6 ay izlem süresinden sonra alektinib tedavisiyle araştırıcıların belirlediği PS'da \%53 risk azalması (Hazard oranı: 0,47; 95\% GA 0,34-0,65; $\mathrm{p}<$ $0,001)$ sağlayarak primer sonlanım noktasını karşılamıştır (8). Çalışmanın 2017'de yayınlanan bu ilk makalesinde henüz alektinib kolunda ortanca PS'ye ulaşılamamış ancak 12-aylık PS \%68,4 olarak (çalışmamızda $\% 74$ ) bildirilmişti. Objektif yanıt oranı ise \%82,9 olarak bildirildi (8). Çalışmamızda bulunan oRR \%78,9 olarak hesaplanmış olup sonuçlar birbirine yakın olarak değerlendirilmiştir. ALEX çalışmasının Mayıs 2020 'de güncellenen sağkalım analizinde ortanca PS 34,8 aya 10,9 ay olarak (Hazard oranı: 0,43) alektinib lehine devam etmiştir ve alektinib kolunda 5-yıllık GS $\% 62,5$ olarak bildirilmiştir (20). Çalışmamızda tedavi almamış 33 hastada 24-aylık PS \%74 olarak hesaplandı ve bu sonuç takip süresi uzadıkça çalışmamızdaki gerçek yaşam verisinin ALEX çalışmasındaki ortanca 34,8 aylık PS'a ulaşma potansiyeli olduğunu düşündürebilir.

Çalışmamızda en az bir tane yan etki bildirilen hasta oranı $\% 34,2$ ve $\geq 3$. derece yan etki $\% 7,9$ olarak bulundu. Yine ALEX çalışmasıyla kıyaslandığında (yan etki \%97 ve $\geq 3$. derece yan etki (\%41) bu oranların oldukça düşük olduğu görülebilir (8). Bu sonucun ortaya çıkmasındaki en büyük faktör çalışmanın retrospektif olması ve tolere edilebilir düşük dereceli yan etkilerin günlük klinik pratikte dokümante edilirken fazla önemsenmemesi olabilir. Bir diğer önemli neden ortanca 9,5 aylık takip süresinin kısa olmasıdir.

Bu iki neden (retrospektif oluşu ve takip süresinin kısalığı) aynı zamanda çalışmamızın en önemli iki zayıf noktasını oluşturmaktadır. Diğer kısıtlılıklar iki merkezden ibaret olması ve hasta sayısının azlığı olarak listelenebilir. Ancak çalışmamızın amacının Alektinib tedavisinin etkinliğini değerlendirmek değil; ALK mutasyonu olan bu hasta grubunun klinik, patolojik, demografik özelliklerini incelemek olduğu göz önünde bulundurulmalıdır. Alektinib tedavisinin etkinliğinin ve yan etkilerinin Türkiye çapında çok merkezli ve daha fazla katılımcı sayısıyla, daha uzun bir takip süresine ulaşacak gerçek yaşam verisiyle değerlendirilmesi ise planlanmaktadır.

Etik Komite Onayı: Bu çalışma Ankara Şehir Hastanesi 2 Nolu Klinik Araştırmalar Etik Kurulunun onayı ile gerçekleştilmiştir (Karar No: E2-21-113, Tarih: 24/02/2021).

\section{ÇIKAR ÇATIŞMASI}

Yazarlar çıkar çatışması bildirmemiştir.

\section{YAZAR KATKISI}

Anafikir/Planlama: $\mathrm{MH}, \mathrm{BB}$

Analiz/Yorum: MH, BB, MAS

Veri sağlama: ŞY, SK, CE, BA, DŞD

Yazım: $\mathrm{MH}$

Gözden Geçirme ve Düzeltme: MH, BB, BY, MAŞ, ŞY, EA

Onaylama: EA, BY, MH

\section{KAYNAKLAR}

1. Bray F, Ferlay J, Soerjomataram I, Siegel RL, Torre LA, Jemal A. Global cancer statistics 2018: GLOBOCAN estimates of incidence and mortality worldwide for 36 cancers in 185 countries. CA Cancer J Clin 2018; 68(6): 394-424.

2. Howlader N, Noone AM, Krapcho M, Miller D, Brest A, Yu M, Ruhl J, Tatalovich Z, Mariotto A, Lewis DR, Chen HS, Feuer EJ, Cronin KA (eds). SEER Cancer Statistics Review, 1975-2016, National Cancer Institute. Available from: https://seer.cancer.gov/csr/1975_2016/ 
Hızal M, Bilgin B, Şendur MA, Yücel Ş, Kahraman S, Erol C ve ark.

3. Ettinger DS. Ten years of progress in non-small cell lung cancer. Journal of the National Comprehensive Cancer Network. JNCCN 2012; 10(3): 292-5.

4. Fois SS, Paliogiannis P, Zinellu A, Fois AG, Cossu A, Palmieri G. Molecular epidemiology of the main druggable genetic alterations in non-small cell lung cancer. Int J Mol Sci $2021 ; 22(2): 612$.

5. Kim H, Chung JH. Overview of clinicopathologic features of ALK-rearranged lung adenocarcinoma and current diagnostic testing for ALK rearrangement. Transl Lung Cancer Res 2015; 4(2): 149-55.

6. Iwahara T, Fujimoto J, Wen D, Cupples $R$, Bucay $N$, Arakawa $T$, et al. Molecular characterization of $A L K$, a receptor tyrosine kinase expressed specifically in the nervous system. Oncogene 1997; 14(4): 439-49.

7. Koh Y, Kim DW, Kim TM, Lee SH, Jeon YK, Chung DH, et al. Clinicopathologic characteristics and outcomes of patients with anaplastic lymphoma kinase-positive advanced pulmonary adenocarcinoma: suggestion for an effective screening strategy for these tumors. I Thorac Oncol 2011; 6(5): 905-12.

8. Peters S, Camidge DR, Shaw AT, Gadgeel S, Ahn JS, Kim $D-W$, et al. Alectinib versus crizotinib in untreated $A L K$ positive non-small-cell lung cancer. N Engl J Med 2017; 377(9): 829-38.

9. Hida T, Nokihara H, Kondo M, Kim YH, Azuma K, Seto T, et al. Alectinib versus crizotinib in patients with $<e m>A L K<1$ em>-positive non-small-cell lung cancer (J-ALEX): an open-label, randomised phase 3 trial. Lancet 2017; 390(10089): 29-39.

10. Zhou C, Kim S-W, Reungwetwattana T, Zhou J, Zhang Y, $\mathrm{He} J$, et al. Alectinib versus crizotinib in untreated Asian patients with anaplastic lymphoma kinase-positive nonsmall-cell lung cancer (ALESIA): a randomised phase 3 study. Lancet Respir Med. 2019; 7(5): 437-46.

11. Therasse P, Arbuck SG, Eisenhauer EA, Wanders J, Kaplan $R S$, Rubinstein $L$, et al. New guidelines to evaluate the response to treatment in solid tumors. European Organization for Research and Treatment of Cancer, National Cancer Institute of the United States, National Cancer Institute of Canada. I Natl Cancer Inst 2000; 92(3): 205-16.
12. Common Terminology Criteria for Adverse Events (CTCAE). U.S Department of Health and Human Services; National Institutes of Health; National Cancer Institute, Version 4.0. Available from URL: http://evs.nci.nih.gov/ftp1/.CTCAE/ CTCAE_4.03_2010-06-14 (Accessed date: 25 Dec 2015).

13. Shaw $A T$, Yeap $B Y$, Mino-Kenudson $M$, Digumarthy $S R$, Costa DB, Heist RS, et al. Clinical features and outcome of patients with non-small-cell lung cancer who harbor EML4-ALK. J Clin Oncol 2009; 27(26): 4247-53.

14. Wang Z, Zhang X, Bai H, Zhao J, Zhuo M, An T, et al. EML4-ALK rearrangement and its clinical significance in Chinese patients with advanced non-small cell lung cancer. Oncology 2012; 83(5): 248-56.

15. Watanabe J, Togo S, Sumiyoshi I, Namba Y, Suina K, Mizuno $T$, et al. Clinical features of squamous cell lung cancer with anaplastic lymphoma kinase (ALK)rearrangement: a retrospective analysis and review. Oncotarget 2018; 9(35): 24000-13.

16. Hirsch FR, Kerr KM, Bunn PA, Kim ES, Obasaju C, Pérol M, et al. Molecular and immune biomarker testing in squamous-cell lung cancer: effect of current and future therapies and technologies. Clinical Lung Cancer 2018; 19(4): 331-9

17. Fallet V, Cadranel J, Doubre H, Toper C, Monnet I, Chinet $T$, et al. Prospective screening for $<\mathrm{em}>A L K</ \mathrm{em}>$ : Clinical features and outcome according to $<\mathrm{em}>A L K</ \mathrm{em}>$ status. Eur I Cancer 2014; 50(7): 1239-46.

18. Guérin A, Sasane M, Zhang J, Culver KW, Dea K, Nitulescu $R$, et al. Brain metastases in patients with ALK+ non-small cell lung cancer: clinical symptoms, treatment patterns and economic burden. J Med Econ 2015; 18(4): 312-22.

19. Johung KL, Yeh N, Desai NB, Williams TM, Lautenschlaeger T, Arvold ND, et al. Extended survival and prognostic factors for patients With ALK-Rearranged non-small-cell lung cancer and brain metastasis. J Clin Oncol 2016; 34(2): 123-9.

20. Mok T, Camidge DR, Gadgeel SM, Rosell R, Dziadziuszko $R$, Kim DW, et al. Updated overall survival and final progression-free survival data for patients with treatmentnaive advanced $<$ em $>A L K</$ em $>$-positive non-small-cell lung cancer in the ALEX study. Ann Oncol 2020; 31(8): 1056-64. 